\title{
Communities of Arbuscular Mycorrhizal Fungi in the Roots of Pyrus pyrifolia var. culta (Japanese Pear) in Orchards with Variable Amounts of Soil-Available Phosphorus
}

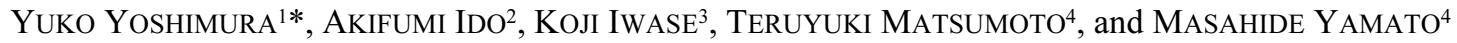 \\ ${ }^{1}$ The United Graduate School of Agricultural Sciences, Tottori University, 4-101 Koyama-Minami, Tottori 680-8553, \\ Japan; ${ }^{2}$ Tottori Prefectural Agriculture and Forest Research Institute, Horticultural Experiment Center, Hokuei, \\ Tohaku, Tottori 689-2221, Japan; ${ }^{3}$ Depertment of Natural and Environmental Science, Teikyo University of Science, \\ 2525 Yatsusawa, Uenohara 409-0193, Japan; and ${ }^{4}$ Fungus/Mushroom Resource and Research Center, Faculty of \\ Agriculture, Tottori University, 4-101 Koyama-Minami, Tottori 680-8553, Japan
}

(Received June 5, 2012—Accepted October 10, 2012—Published online December 19, 2012)

\begin{abstract}
We examined the colonization rate and communities of arbuscular mycorrhizal fungi (AMF) in the roots of Pyrus pyrifolia var. culta (Japanese pear) in orchards to investigate the effect of phosphorus (P) fertilization on AMF. Soil cores containing the roots of Japanese pear were collected from 13 orchards in Tottori Prefecture, Japan. Soil-available $\mathrm{P}$ in the examined orchards was 75.7 to $1,200 \mathrm{mg} \mathrm{kg}^{-1}$, showing the extreme accumulation of soil $\mathrm{P}$ in many orchards. The AMF colonization rate was negatively correlated with soil-available $\mathrm{P}(P<0.01)$. AMF communities were examined on the basis of the partial fungal DNA sequences of the nuclear small-subunit ribosomal RNA gene (SSU rDNA) amplified by AMF-specific primers AML1 and AML2. The obtained AMF sequences were divided into 14 phylotypes, and the number of phylotypes (species richness) was also negatively correlated with soil-available $\mathrm{P}(P<0.05)$. It was also suggested that some AM fungi may be adapted to high soil-available $\mathrm{P}$ conditions. Redundancy analysis showed the significant effects of soil $\mathrm{pH}$, available $\mathrm{P}$ in soil, and $\mathrm{P}$ content in leaves of $P$. pyrifolia var. culta trees on AMF distribution. These results suggested that the accumulation of soil-available P affected AMF communities in the roots of Japanese pear in the orchard environment.
\end{abstract}

Key words: AML1-AML2, principal component analysis (PCA), redundancy analysis (RDA), soil-available P, SSU rDNA

Arbuscular mycorrhizal fungi (AMF) are ubiquitous in most terrestrial plant communities and form mutualistic associations with the majority of plant species (46). This symbiosis confers the host plants with numerous benefits such as growth promotion through improved mineral nutrients, particularly phosphorus $(\mathrm{P})$, and alleviation of diseases (6) and abiotic stresses, namely drought (5), heavy metal toxicity (32), salinity (17), etc. AMF symbioses usually display less specificity under pot culture conditions with inoculation of a single fungal strain (46); however, some studies have revealed that AMF communities differ among different plant species in the same ecosystem, which indicates the existence of preferences between plants and AMF (52, 53). The effect of floristic composition on AMF communities was also experimentally demonstrated in a grassland microcosm (24). Furthermore, AMF have functionally diversified to have different effects on plant growth $(31,47)$. These results suggested the importance of AMF communities in plant ecosystems. Because of their importance for agricultural plants, AMF could be used to minimize the dependence on chemical fertilizers; however, mycorrhizal technology is not much utilized in agricultural practice because of the poor understanding of the basic biology and ecology of AMF in agricultural ecosystems.

Many studies have demonstrated that the AMF colonization

\footnotetext{
* Corresponding author. E-mail: k0625339@kadai.jp;
}

Tel: +81-857-31-5343; Fax: +81-857-31-5347. rate decreases with the addition of $\mathrm{P}$ to the soil $(1,12,34$, $42,48,50)$. The effect of increasing soil-available $\mathrm{P}$ on the AMF colonization rate can differ depending on the AMF species. For example, Thomson et al. (50) reported that the percentage of root length colonized by Gigaspora calospora was decreased by a greater extent than that of Glomus fasciculatum with increasing soil-available P. In agricultural systems, some studies have shown that higher levels of inorganic fertilizer input resulted in lower AMF diversity $(13,20,36)$. Moreover, it was also suggested that less efficient AMF might be selected with high fertilizer input $(25,45)$.

Soil-available P in arable land in Japan has been increasing (35). It is often excessive, especially in orchards, because of the repeated application of chemical fertilizers, which may have some detrimental effects on AMF. Ishii et al. (22) showed that AMF proliferation was suppressed in citrus orchards with high levels of P. Youpensuk et al. (56) also found that AMF root colonization rates and spore densities were significantly decreased in tangerine (Citrus reticulate) orchards containing more than $500 \mathrm{mg} \mathrm{kg}^{-1}$ of available $\mathrm{P}$ in soil.

Pears (genus Pyrus, Rosaceae) are cultivated for eating throughout the world. Orchard trees of Rosaceae are known to be host plants of AMF $(10,11,39,40,41)$. For $P$. commun L., growth enhancement was shown for seedlings with AMF inoculation (16). Moreover, Lopez et al. (30) showed that foliar levels of $\mathrm{N}, \mathrm{P}$, and $\mathrm{Zn}$ of $P$. commun rootstock were increased by Glomus intraradices and G. mosseae inocula- 
tions under field conditions. P. pyrifolia var. culta (Japanese pear) is a widely cultivated fruit tree species in Japan; however, there has been little research into AMF for this tree species. In the present study, we examined the colonization rates and communities of AMF in the roots of $P$. pyrifolia var. culta in 13 orchards in Tottori Pref., Japan, as well as soil chemical properties to investigate the effect of fertilization on AMF.

\section{Materials and Methods}

\section{Sampling}

In Tottori Prefecture, 13 orchards managed by different farmers were selected as the study sites (Table 1), and sampling was conducted in June and July 2010. For sampling, four trees of $P$. pyrifolia var. culta cultivar 'Osa-Gold' were randomly selected in each orchard, and three soil core samples $(5 \mathrm{~cm}$ in diameter and 10 $\mathrm{cm}$ in depth) containing roots of Japanese pear were collected from three points at a distance of approximately $70 \mathrm{~cm}$ from the tree base. The three soil cores were mixed to prepare one soil sample. Furthermore, 10 leaves were collected from the middle of the spurs for each selected tree.

\section{Soil chemical analysis}

Soil samples collected from the soil cores were dried at room temperature for a week after removing root samples. They were then analyzed for soil chemical properties. The soil $\mathrm{pH}\left(\mathrm{H}_{2} \mathrm{O}\right)$ at 1:2.5 of the soil-water ratio and the available P (Truog P; 51) were measured. Total $\mathrm{C}$ and total $\mathrm{N}$ were analyzed using an Elementar varioEL CHNS analyser (Elementar, Hanau, Germany).

\section{Leaf P content}

The collected pear leaves were washed with tap water, rinsed with distilled water, and then dried at $70^{\circ} \mathrm{C}$ for $48 \mathrm{~h}$. The leaves were ground using an Oster Blender (Osaka Chemical, Osaka, Japan) and the leaf samples were then digested using $\mathrm{H}_{2} \mathrm{SO}_{4}$ and $\mathrm{H}_{2} \mathrm{O}_{2}$ in a heat block at approximately $200^{\circ} \mathrm{C}$. Subsequently, leaf P content was determined using the vanadomolybdate spectrophotometric method (8).

\section{AMF colonization rate}

Root samples were carefully washed with tap water to remove attached soil debris, and fine roots were collected. AMF colonization rates were determined using approximately $15 \mathrm{mg}$ fresh fine roots according to the method of Brundrett et al. (9) as follows. The fine roots were cleared in $10 \% \mathrm{KOH}$ at $121^{\circ} \mathrm{C}$ for 20 min by autoclaving. After sequential rinsing with distilled water, alkaline $\mathrm{H}_{2} \mathrm{O}_{2}$, and $2 \%$ $\mathrm{HCl}$, the roots were stained with $0.05 \%$ trypan blue at $100^{\circ} \mathrm{C}$ in a

Table 1. Location of the study sites

\begin{tabular}{lcc}
\hline \multicolumn{1}{c}{ Study site } & Latitude & Longitude \\
\hline Aimi (Ai) & $35^{\circ} 20.9^{\prime} \mathrm{N}$ & $133^{\circ} 24.2^{\prime} \mathrm{E}$ \\
Nawa (Nw) & $35^{\circ} 30.0^{\prime} \mathrm{N}$ & $133^{\circ} 30.5^{\prime} \mathrm{E}$ \\
Nakayama (Nk) & $35^{\circ} 30.7^{\prime} \mathrm{N}$ & $133^{\circ} 33.9^{\prime} \mathrm{E}$ \\
Akasaki (Ak) & $35^{\circ} 27.8^{\prime} \mathrm{N}$ & $133^{\circ} 38.3^{\prime} \mathrm{E}$ \\
Tohaku (Th) & $35^{\circ} 29.3^{\prime} \mathrm{N}$ & $133^{\circ} 39.2^{\prime} \mathrm{E}$ \\
Kurayoshi (Ku) & $35^{\circ} 23.4^{\prime} \mathrm{N}$ & $133^{\circ} 44.7^{\prime} \mathrm{E}$ \\
Togo (Tg) & $35^{\circ} 28.0^{\prime} \mathrm{N}$ & $133^{\circ} 55.1^{\prime} \mathrm{E}$ \\
Yura (YuA, YuB)* & $35^{\circ} 28.5^{\prime} \mathrm{N}$ & $133^{\circ} 44.5^{\prime} \mathrm{E}$ \\
Otsuka (Ot) & $35^{\circ} 29.0^{\prime} \mathrm{N}$ & $134^{\circ} 09.1^{\prime} \mathrm{E}$ \\
Kawahara (Ka) & $35^{\circ} 23.5^{\prime} \mathrm{N}$ & $134^{\circ} 11.2^{\prime} \mathrm{E}$ \\
Koge (Ko) & $35^{\circ} 24.5^{\prime} \mathrm{N}$ & $134^{\circ} 19.9^{\prime} \mathrm{E}$ \\
Fukube (Fu) & $35^{\circ} 32.4^{\prime} \mathrm{N}$ & $134^{\circ} 15.4^{\prime} \mathrm{E}$ \\
\hline
\end{tabular}

* Two different fertilized conditions (A, B) were included in 'Yura'. 'A' was not fertilized, and 'B' had conventional fertilization. water bath for $10 \mathrm{~min}$. The stained roots were then stored in a lactic acid:glycerol:water $(1: 1: 1)$ solution. The AMF colonization rate was determined by the gridline intersection method with at least 100 intersections.

\section{Molecular diversity analysis}

DNA was extracted from of the remaining fresh fine roots ( $c a$. 20-50 mg) using a DNeasy Plant Mini Kit (Qiagen, Hilden, Germany). A partial sequence (approximately $750 \mathrm{bp}$ ) of the AM fungal nuclear small-subunit ribosomal RNA gene (SSU rDNA) was amplified by polymerase chain reaction (PCR) from $1 \mu \mathrm{L}$ extracted DNA solution using the AMF-specific primers AML1 and AML2 (28) with Takara Ex TaqHot Start Version (Takara Bio, Otsu, Japan). PCR was performed using a Program Temp Control System (Astec, Fukuoka, Japan) in a total volume of $30 \mu \mathrm{L}$ containing $0.15 \mu \mathrm{L}$ Taq DNA polymerase, $3 \mu \mathrm{L}$ PCR buffer (consisting of $100 \mathrm{mM}$ Tris- $\mathrm{HCl}(\mathrm{pH} 8.3), 500 \mathrm{mM} \mathrm{KCl}$ and 15 $\mathrm{mM} \mathrm{MgCl} 2$ ), $200 \mu \mathrm{M}$ of each deoxynucleotide triphosphate (dNTP), and $0.25 \mu \mathrm{M}$ of each primer. The PCR conditions were as follows: an initial denaturation step at $94^{\circ} \mathrm{C}$ for $2 \mathrm{~min}$, followed by 35 cycles of $94^{\circ} \mathrm{C}$ for $30 \mathrm{~s}, 50^{\circ} \mathrm{C}$ for $30 \mathrm{~s}$, and $72^{\circ} \mathrm{C}$ for $1 \mathrm{~min}$, and a final elongation step at $72^{\circ} \mathrm{C}$ for $5 \mathrm{~min}$. After purification using the Gel Indicator DNA Extraction Kit (BioDynamics Laboratory, Tokyo, Japan), the PCR products were ligated into pGEM-T Easy Vector System I (Promega, Madison, WI, USA) according to the manufacturer's instructions. They were then transformed into competent cells (Competent high DH5 $\alpha$; Toyobo, Osaka, Japan). For each sample, at least 16 cloned products (white colonies) were randomly selected, and the plasmid DNA containing the PCR product was extracted from $1.5 \mathrm{~mL}$ cultured competent cells using the Mag Extractor Plasmid (Toyobo, Osaka, Japan). The DNA inserts were sequenced using a BigDye Terminator v3.1 Cycle Sequencing Kit (Applied Biosystems, Carlsbad, CA. USA) and the promoter primers T7 and SP6 on a 3130 Genetic Analyzer (Hitachi, Tokyo, Japan). For all sequenced data, multiple sequence alignments were performed using ClustalX version 2.0.12 (27). The aligned sequences were analyzed by the neighbor-joining method (43) with bootstrap analyses of 1,000 replications (15). The phylogenetic trees were drawn using TreeView (38). AMF phylotypes were defined on the basis of tree topology and sequence similarity computed by ClustalX. A rarefaction curve was computed for each sample by plotting the number of AMF phylotypes detected against the number of sequences using Analytic Rarefaction version 1.3 (https://www.uga. edu/_strata/software/AnRare/Readme.html). For each sample, additional clones were sequenced until the rarefaction curve tended to plateau.

Some representative DNA sequences were arbitrarily selected for each AMF phylotype and deposited into the DNA Data Bank of Japan (DDBJ) database with accession numbers AB694978AB695066. The selected sequences were subjected to BLAST searches (3), and the similar sequences were downloaded from the GenBank database. Multiple sequence alignments, neighbor-joining analysis, and phylogenetic tree drawing were performed as described above for the sequenced and downloaded data.

\section{Data analysis}

The relationships between the soil chemical properties or leaf $\mathrm{P}$ and $\mathrm{AMF}$ colonization rates or number of AMF phylotypes were investigated by Pearson's correlation coefficient test.

To examine the relationship between the AMF distribution and the environmental factors, multivariate analyses were performed using CANOCO 4.5 (49). In the data table of response variables, i.e., the distribution of AMF phylotypes, the presence or absence of each phylotype was scored as so-called dummy variables (" 1 " and " 0 " for the presence and absence, respectively) in each sample. For the data of 
explanatory (environmental) variables, soil-available $\mathrm{P}$, soil $\mathrm{pH}$, soil total $\mathrm{C}$, soil total $\mathrm{N}$, and leaf $\mathrm{P}$ content were used. First, detrended correspondence analysis (DCA) was performed for the response variable data to estimate the heterogeneity through the length of the community composition gradients in species turnover units. DCA was performed with detrending by segments. After confirming the length of the community composition gradients on the first DCA axis, principal component analysis (PCA) was performed to infer the relationship between AMF distribution and the environmental variables. PCA was performed with scaling on interspecies correlations with division by standard deviation and centering by species. The resulting diagram was displayed using CanoDraw. To evaluate the effects of environmental variables, redundancy analysis (RDA) was then applied with scaling on interspecies correlations with division by standard deviation and centering by species, in which Monte Carlo permutation tests with unrestricted 999 permutations were performed for manually selected environmental variables.

\section{Results}

\section{Soil analysis and AMF colonization rates}

The soil type of the examined area was basically andosol caused by volcanic ash; however, the soil color was not blackish in most examined orchards because of the disappearance of topsoil during the preparation of orchards. The soil chemical properties and AMF colonization rates are shown in Table 2. The soil-available $\mathrm{P}$ was found to vary markedly, 75.7 to $1,200 \mathrm{mg} \mathrm{kg}^{-1}$. The AMF colonization rate was determined for 45 samples having sufficient fine roots for examination. The rate varied from 0.2 to $71.9 \%$, which was negatively correlated with the amount of soil-available $\mathrm{P}$ with a coefficient of $-0.39(P<0.01)$ (Fig. 1). For other soil chemical properties and leaf $P$, significant correlations were not found in the relationships with AMF colonization rates (Table $\mathrm{S} 1)$.

\section{Molecular analysis on AMF community}

For 39 samples having sufficient fine roots for examination (ca. 20-50 mg), molecular analysis was performed to examine the AMF communities. For each sample, 16-36 clones were sequenced. After excluding putative chimera sequences, 618 sequences were obtained. All of the obtained sequences were divided into 14 phylotypes by neighbor-joining phylogenetic analysis so that each phylotype had sequence similarity of more than $96 \%$. Each phylotype was determined to include at least 3 sequences obtained. Eleven of the phylotypes were Glomus, and one each was Paraglomus, Acaulospora, and Diversispora. All phylotypes were supported by bootstrap values of more than $70 \%$. For the taxonomy of AMF, new revised genera based on the molecular phylogeny were proposed $(26,44)$, and the new genera were shown for the identified AMF species in the phylogenetic tree (Fig. 2); however, allocations to the new genera were difficult for most of the phylotypes in this study because of the lack of related identified species. Thus, we used the former taxonomy based on the spore morphologies to express the phylotypes. The phylogenetic trees constructed using selected and downloaded DNA sequences are shown in Fig. 2. Only two phylotypes were affiliated with morphologically identified AMF species: Glo1 with $G$. intraradices (Rhizophagus intraradices) and Div1 with Diversispora epigaea. The number of AMF phylotypes was negatively correlated with soil-available $\mathrm{P}$ with a coefficient of $-0.39(P<0.05)$ (Fig. 3 ). Investigation of the relationship between the distribution of AMF phylotypes and the available $\mathrm{P}$ showed that only four AMF phylotypes, i.e., Glo1, Glo2 Glo5, and Div1, were detected in the soil with more than $800 \mathrm{mg} \mathrm{kg}^{-1}$ of available $\mathrm{P}$ (Fig. 4). For other soil chemical properties and leaf P, significant correlations were not found in the relationships with the number of AMF phylotypes (Table S1).

\section{AMF community and environmental variables}

From DCA for the response variable data, the length of the community composition gradients of the first axis was computed to be 3.63. From this result, we used PCA as the linear ordination method. The resulting ordination is presented in Fig. 5. The eigenvalues of the first and second axes were 0.242 and 0.214 , respectively. The cumulative percentage variance of species data showed that the first two PCA axes explain $45.7 \%$ of the variability in species data. PCA on AMF distribution and environmental variables suggested that many AMF prefer soil conditions with lower available soil $\mathrm{P}$. The relative preference for higher soilavailable P in Glo1, Glo2, and Glo5 AMF was also suggested in PCA. The results of Monte Carlo permutation tests on RDA indicated that environmental variables, such as soil $\mathrm{pH}$, soil-available $\mathrm{P}$, and leaf $\mathrm{P}$, affected the AMF distribution significantly $(P<0.05)$, in which the effect of soil available $\mathrm{P}$ was stronger than that of leaf $\mathrm{P}$ (Table 3). These results suggested that soil $\mathrm{P}$ accumulation caused by fertilization could be an influential factor on AMF communities in the examined orchards.

\section{Discussion}

Most AMF detected in the roots of Japanese pear in this study were Glomus spp., although Paraglomus, Acaulospora, and Diversispora spp. were also detected (Fig. 2). Lee et al. (28) reported that the PCR primer set AML1 and AML2 used in this study can amplify the sequences of most AMF, and their adaptation for diverse AMF taxa was confirmed in this study; therefore, the dominant detection of Glomus fungi in the roots of Japanese pear can be a reflection of the actual AMF communities.

Most DNA sequences obtained in this study were not closely related to those of any morphologically identified AMF species in the GenBank database. Other studies also revealed that most AMF in tree roots are not closely related to the identified AMF species $(7,19,21,55)$. For Rosaceae trees, Wubet et al. (54) investigated the molecular diversity of AMF in Prunus africana in the dry afromontane forests of Ethiopia. In phylogenetic analysis, they detected 21 phylotypes, most of which were not assigned to known AMF species. These results may indicate that AMF colonizing tree roots are not inclined to produce conspicuous spores.

The AMF sequences were divided into 14 phylotypes (Fig. 2 ). Significant negative correlations were found between the 
soil-available $\mathrm{P}$ and the AMF colonization rate or the number of AMF phylotypes (AMF species richness) (Figs. 1 and 3). This result is consistent with some previous studies $(2,14$, 29). The figures suggested that the effect of soil-available $P$ on the AMF colonization rate or the number of AMF phylotypes became obvious at certain levels, e.g., $800 \mathrm{mg}$ $\mathrm{kg}^{-1}$ for AMF rate and $500 \mathrm{mg} \mathrm{kg} \mathrm{kg}^{-1}$ for AMF phylotypes, respectively. Meanwhile, the correlations between leaf $P$ and AMF rate or AMF species richness were not significant. RDA on the AMF distribution and environmental variables showed that soil $\mathrm{pH}$, soil-available $\mathrm{P}$, and leaf $\mathrm{P}$ had significant relationships with the AMF distribution in the roots of Japanese pears, in which the effect of soil-available P was stronger than that of leaf $\mathrm{P}$ (Table 3). The detrimental effects

Table 2. Soil chemical properties, leaf $\mathrm{P}, \mathrm{AMF}$ colonization rate, and number of phylotypes in each sample

\begin{tabular}{|c|c|c|c|c|c|c|c|}
\hline Sample & Soil pH & $\begin{array}{l}\text { Soil available } P \\
\quad\left(\mathrm{mg} \mathrm{kg}^{-1}\right)\end{array}$ & $\begin{array}{l}\text { Soil total N } \\
\left(\mathrm{g} \mathrm{kg}^{-1}\right)\end{array}$ & $\begin{array}{l}\text { Soil total C } \\
\left(\mathrm{g} \mathrm{kg}^{-1}\right)\end{array}$ & $\begin{array}{c}\text { Leaf P } \\
\left(\mathrm{mg} \mathrm{g}^{-1}\right)\end{array}$ & $\begin{array}{c}\text { AMF } \\
\text { colonization } \\
\text { rate }(\%)\end{array}$ & $\begin{array}{l}\text { Number of } \\
\text { AMF } \\
\text { phylotypes }\end{array}$ \\
\hline $\operatorname{Aimi}(\mathrm{Ai}) 1$ & 5.7 & 381.2 & 3.40 & 42.0 & 2.7 & 24.9 & 3 \\
\hline 2 & 5.3 & 257.8 & 3.82 & 62.1 & 2.0 & 30.3 & 4 \\
\hline 3 & 5.5 & 426.7 & 4.34 & 67.9 & 1.9 & 18.6 & 3 \\
\hline 4 & 6.1 & 497.0 & 3.93 & 52.1 & 1.8 & 1.8 & - \\
\hline Nawa (Nw) 1 & 6.3 & 468.5 & 2.97 & 36.5 & 2.2 & 50.4 & 2 \\
\hline 2 & 6.1 & 510.3 & 3.12 & 36.6 & 2.1 & 71.0 & 5 \\
\hline 3 & 5.7 & 286.3 & 3.08 & 41.4 & 1.8 & 51.6 & 4 \\
\hline 4 & 6.4 & 459.0 & 3.76 & 47.0 & 2.0 & 67.9 & 3 \\
\hline Nakayama (Nk) 1 & 6.3 & 390.7 & 5.37 & 83.4 & 2.9 & 30.3 & 5 \\
\hline 2 & 6.5 & 542.5 & 5.15 & 80.8 & 2.7 & 40.1 & 3 \\
\hline 3 & 6.4 & 677.3 & 5.66 & 91.1 & 2.4 & 35.8 & 3 \\
\hline 4 & 6.5 & 607.1 & 4.78 & 66.7 & 2.6 & 61.3 & 3 \\
\hline Akasaki (Ak) 1 & 7.0 & 967.4 & 4.87 & 51.2 & 2.2 & 26.8 & 1 \\
\hline 2 & 7.0 & 745.7 & 4.31 & 41.7 & 1.8 & - & - \\
\hline 3 & 7.0 & 1,036 & 5.11 & 63.2 & 2.2 & 24.8 & 3 \\
\hline 4 & 7.0 & 1,136 & 3.95 & 41.0 & 2.3 & - & - \\
\hline Tohaku (Th) 1 & 4.8 & 590.6 & 6.80 & 83.5 & 2.0 & 0.2 & - \\
\hline 2 & 4.1 & 488.1 & 5.62 & 74.3 & 2.0 & 0.5 & - \\
\hline 3 & 4.4 & 605.8 & 6.05 & 76.4 & 2.3 & 6.5 & 1 \\
\hline 4 & 5.0 & 721.6 & 4.95 & 58.9 & 2.2 & 17.3 & 1 \\
\hline Kurayoshi (Ku) 1 & 5.2 & 227.9 & 7.72 & 129.0 & 2.6 & 57.7 & 1 \\
\hline 2 & 5.3 & 165.2 & 7.40 & 122.5 & 2.7 & 54.0 & 2 \\
\hline 3 & 5.5 & 169.6 & 6.98 & 111.4 & 2.4 & 65.7 & 2 \\
\hline 4 & 5.6 & 257.0 & 6.31 & 95.5 & 2.4 & 57.6 & 6 \\
\hline Togo (Tg) 1 & 5.3 & 882.2 & 2.77 & 32.0 & 2.6 & - & - \\
\hline 2 & 5.3 & 527.9 & 2.07 & 24.9 & 2.3 & 11.6 & 2 \\
\hline 3 & 5.8 & 687.4 & 2.21 & 26.7 & 2.3 & 8.4 & 2 \\
\hline 4 & 5.3 & 396.9 & 2.09 & 26.4 & 2.5 & 41.8 & 2 \\
\hline Yura A (YuA) 1 & 6.1 & 136.4 & 3.81 & 44.0 & 2.7 & 71.9 & 6 \\
\hline 2 & 6.2 & 75.7 & 3.04 & 34.9 & 2.1 & 50.6 & 3 \\
\hline 3 & 5.3 & 130.7 & 4.17 & 43.0 & 2.4 & 48.3 & 6 \\
\hline 4 & 5.3 & 188.9 & 4.03 & 45.3 & 2.4 & 34.0 & 2 \\
\hline Yura B (YuB) 1 & 4.6 & 192.1 & 4.03 & 44.6 & 2.3 & 61.1 & 3 \\
\hline 2 & 5.2 & 163.0 & 2.99 & 35.1 & 2.6 & 72.1 & 2 \\
\hline 3 & 4.6 & 273.1 & 3.53 & 38.0 & 2.5 & 23.3 & - \\
\hline 4 & 5.0 & 225.7 & 2.56 & 29.2 & 2.5 & 14.6 & - \\
\hline Otsuka (Ot) 1 & 6.6 & 1,106 & 4.28 & 48.1 & 1.9 & 25.9 & 2 \\
\hline 2 & 6.7 & 959.9 & 4.03 & 48.3 & 2.2 & - & - \\
\hline 3 & 6.6 & 1,137 & 4.64 & 55.4 & 2.1 & - & - \\
\hline 4 & 6.4 & 896.7 & 3.58 & 42.5 & 2.2 & 38.0 & 2 \\
\hline Kawahara (Ka) 1 & 5.2 & 362.8 & 2.75 & 39.9 & 2.1 & 69.5 & 4 \\
\hline 2 & 4.9 & 227.5 & 2.65 & 39.8 & 1.9 & - & - \\
\hline 3 & 4.8 & 343.8 & 3.19 & 47.2 & 1.8 & 49.6 & 2 \\
\hline 4 & 4.8 & 180.1 & 2.70 & 40.8 & 2.1 & 52.0 & - \\
\hline Koge (Ko) 1 & 6.6 & 985.2 & 2.87 & 31.1 & 2.4 & 23.8 & 2 \\
\hline 2 & 6.5 & 767.1 & 2.58 & 27.8 & 2.7 & 55.7 & 2 \\
\hline 3 & 6.8 & 1,200 & 3.19 & 34.8 & 2.1 & - & - \\
\hline 4 & 6.5 & 816.5 & 2.80 & 31.1 & 2.5 & 47.0 & 1 \\
\hline Fukube (Fu) 1 & 5.7 & 338.1 & 3.95 & 49.3 & 2.5 & 44.0 & 5 \\
\hline 2 & 6.4 & 334.3 & 4.77 & 60.8 & 2.7 & 35.2 & 2 \\
\hline 3 & 6.4 & 427.3 & 2.78 & 35.0 & 2.5 & 33.3 & 6 \\
\hline 4 & 6.2 & 433.0 & 3.04 & 34.4 & 2.7 & 25.0 & 2 \\
\hline
\end{tabular}




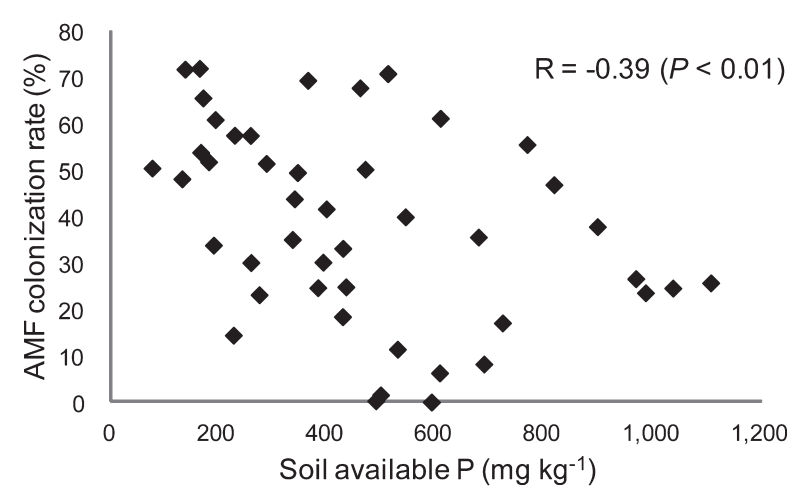

Fig. 1. Correlation between soil-available phosphorus $(\mathrm{P})$ and the colonization rate of arbuscular mycorrhizal fungi (AMF) in the roots of Pyrus pyrifolia var. culta (Japanese pear).

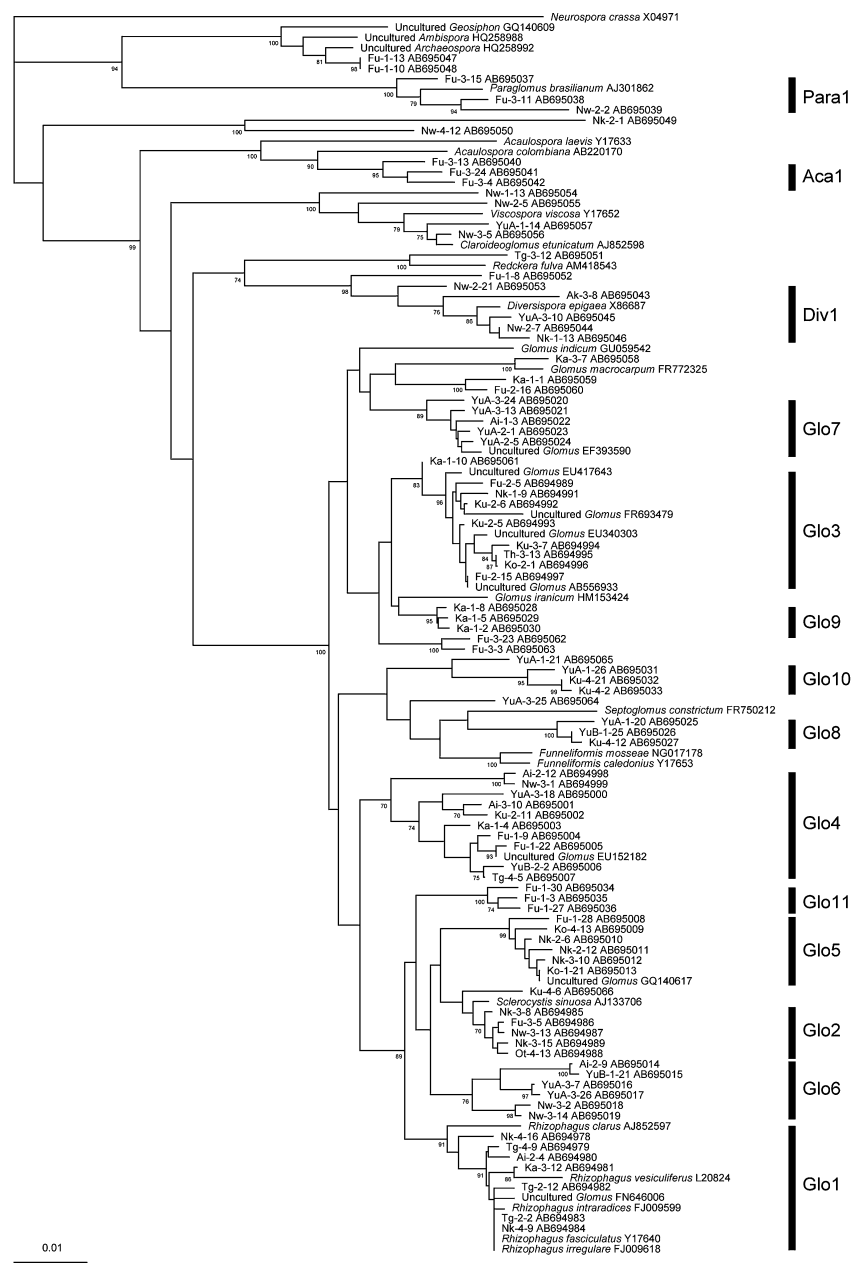

Fig. 2. A neighbor-joining phylogenetic tree based on partial sequences of SSU rDNA of arbuscular mycorrhizal fungi (AMF) in the roots of Pyrus pyrifolia var. culta (Japanese pear) and in the GenBank database. The tree is rooted to Neurospora crassa (X04971) in Ascomycota. The sequence numbers are related to the orchard, tree, and clone numbers. The division of phylotypes (Glo1-Glo11, Acal, Div1, and Para1) is shown. Bootstrap values are shown when they exceed $70 \%$ (1,000 replications). The scale is shown so that evolutionary distances can be inferred. Accession numbers are given for all sequences.

of soil-available $\mathrm{P}$ on AMF colonization have been believed to be caused by changes in the P status of the plant $(23,33)$; however, examination of the relationships between the $\mathrm{P}$

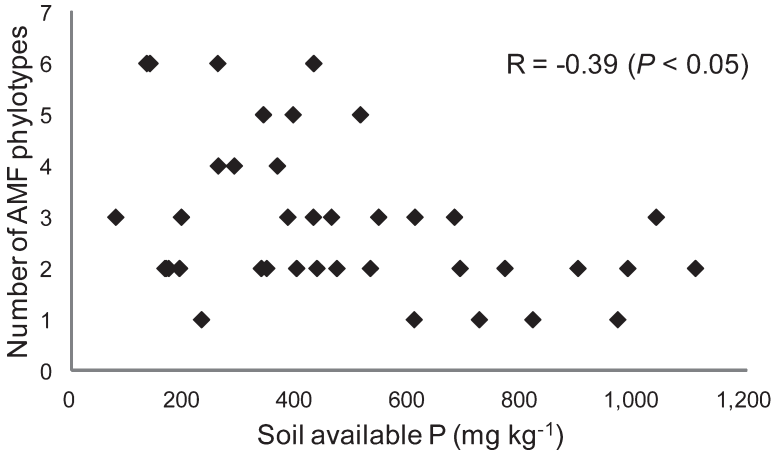

Fig. 3. Correlation between soil-available phosphorus $(\mathrm{P})$ and the number of phylotypes of arbuscular mycorrhizal fungi (AMF) in the roots of Pyrus pyrifolia var. culta (Japanese pear).

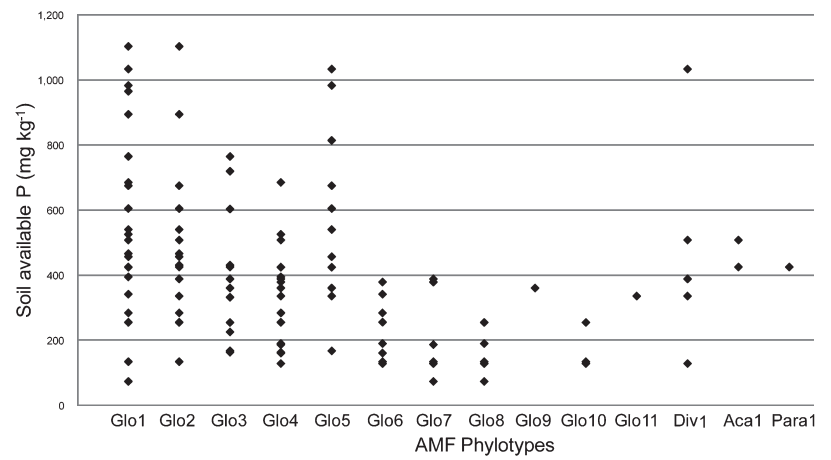

Fig. 4. Relationship between soil-available phosphorus (P) and the distribution of phylotypes of arbuscular mycorrhizal fungi (AMF) in the roots of Pyrus pyrifolia var. culta (Japanese pear).

status of trees and the AMF colonization at local roots is difficult under field conditions, especially in orchards. Leaf $\mathrm{P}$ can reflect overall $\mathrm{P}$ absorption by roots and AMF, and the absorption area includes less fertilized areas and deeper zones; however, the roots in these areas were not evaluated for AMF in this study. It is probable that AMF colonization can be controlled by the $\mathrm{P}$ status of each local root through local reaction for enhanced $\mathrm{P}$ flux rather than the $\mathrm{P}$ status of the whole plant (18), and this may be the reason for the stronger effect of soil $\mathrm{P}$ on AMF than leaf $\mathrm{P}$ in this study. Soil $\mathrm{pH}$ was another factor that strongly affected AMF distribution. An et al. (4) also showed that soil $\mathrm{pH}$ could be a driving force for AMF communities in comparisons of those in acid sulfate soils and a non-acidic sandy soil; however, the soil $\mathrm{pH}$ of the examined orchards in this study was determined by various factors, such as original soil $\mathrm{pH}$, amount of lime and/or magnesia, and fertilizers applied. Because these factors themselves may also affect AMF communities, we refrained from discussing the effect of $\mathrm{pH}$ alone. The effects of soil total $\mathrm{C}$ and soil total $\mathrm{N}$ were smaller than those of soil-available $\mathrm{P}$ and soil $\mathrm{pH}$ (Table 3).

In Japan, the recommended level of available $\mathrm{P}$ in orchard soil is $44-131 \mathrm{mg} \mathrm{kg} \mathrm{kg}^{-1}$ according to the Ministry of Agriculture, Forestry, and Fisheries (http://www.maff.go.jp/ $\mathrm{j} /$ seisan/kankyo/hozen_type/h_dozyo/pdf/chi4.pdf); however, almost all soil samples examined in this study had much higher available $P$ content. Some AMF phylotypes were found to be dominant under higher soil-available $\mathrm{P}$ conditions. Glo1 


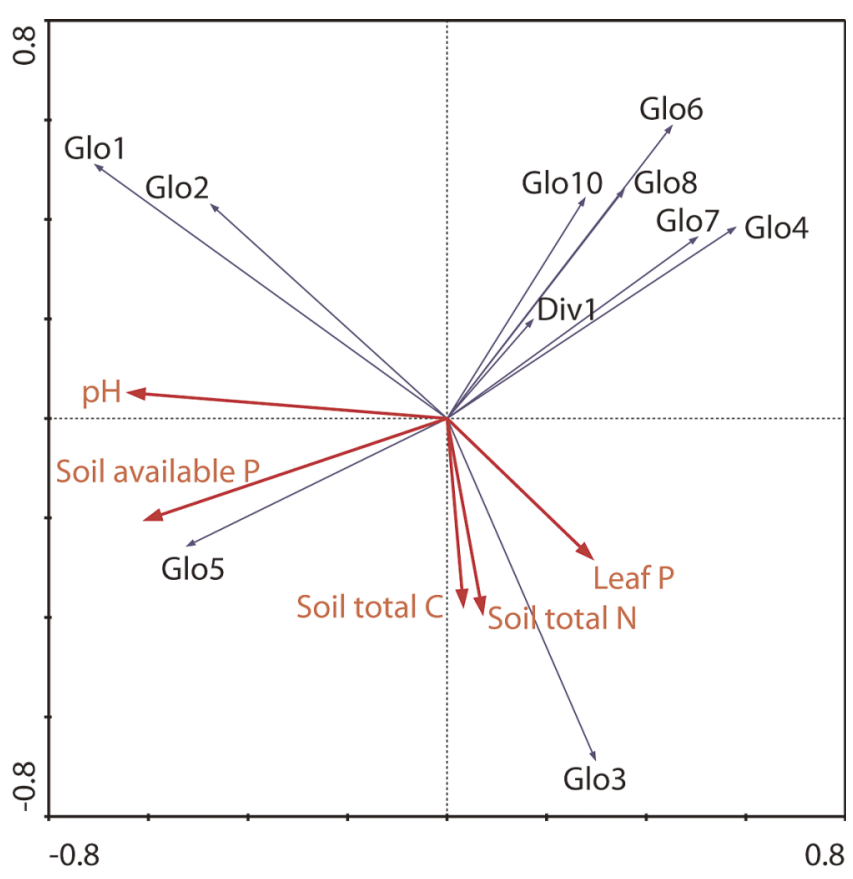

Fig. 5. Diagram of principal component analysis (PCA) on communities of arbuscular mycorrhizal fungi (AMF) with environmental variables, soil-available $\mathrm{P}$, soil $\mathrm{pH}$, soil total nitrogen $(\mathrm{N})$, soil total carbon (C), and $\mathrm{P}$ content in the leaves (leaf $\mathrm{P}$ ), in the examined orchards of Pyrus pyrifolia var. culta (Japanese pear). The eigenvalues of the first and second PCA axes were 0.242 and 0.214 , respectively.

Table 3. Result of Monte Carlo permutation tests ( 999 permutations) from redundancy analysis (RDA) of the effect of environmental variables on arbuscular mycorrhizal fungal community

\begin{tabular}{lcc}
\hline $\begin{array}{c}\text { Environmental } \\
\text { variables }\end{array}$ & $F$ value & $P$ value \\
\hline Soil pH & 4.69 & 0.001 \\
Soil vailable $\mathrm{P}$ & 4.45 & 0.001 \\
Leaf P & 2.27 & 0.032 \\
Soil total N & 2.04 & 0.054 \\
Soil total C & 1.78 & 0.072 \\
\hline
\end{tabular}

is one such AMF phylotype, and this AMF phylotype includes G. intraradices. This AMF species is known as a generalist because it has been found in various environments such as tropical forests, grasslands, temperate deciduous forests, and arable fields (37). Increased abundance of $G$. intraradices in response to fertilization was also found by Johnson (25), who also showed that fertilization changed the composition of AMF communities in field plots, in which AMF from fertilized soil was found to have reduced effects on plant growth. Scullion et al. (45) also reported that AMF inocula from organic farms were more effective than those from conventional farms with high fertilizer input. These studies suggested that intensive fertilization may select some AMF with inferior effects on host plants.

The negative correlations between soil-available $\mathrm{P}$ and the AMF colonization rate or AMF species richness shown in this study suggested that agricultural practices with excessive fertilization could negate the advantages of AMF. In order to utilize the positive functions of AMF symbiosis in orchards, appropriate application amounts of fertilizer should be further studied with consideration of AMF.

\section{Acknowledgements}

We express our gratitude to Dr. Hiroaki Itai from Tottori University for his kind assistance in this study. We also express our thanks to the Horticultural Experiment Station of Tottori Agricultural and Forestry Research Institute for permitting this study in the experimental fields. We are grateful to Dr. Roger Tai Koide for his kind help in reviewing the manuscript. This study was supported by the Global COE Program "Advanced Utilization of Fungus/ Mushroom Resources for Sustainable Society in Harmony with Nature" from the Ministry of Education, Culture, Sports, Science and Technology of Japan.

\section{References}

1. Abbott, L.K., A.D. Robson, and G. De Boer. 1984. The effect of phosphorus on the formation of hyphae in soil by the vesiculararbuscular mycorrhizal fungus, Glomus fasciculatum. New Phytol. 97:437-446.

2. Alguacil, M.M., Z. Lozano, M.J. Campoy, and A. Roldán. 2010. Phosphorus fertilization managementmodifies the biodiversity of AM fungi in a tropical savanna forage system. Soil Biol. Biochem. 42:1114-1122.

3. Altschul, S.F., T.L. Madden, A.A. Schäffer, J. Zhang, Z. Zhang, W. Miller, and D.J. Lipman. 1997. Gapped BLAST and PSI-BLAST: a new generation of protein database search programs. Nucleic Acids Res. 25:3389-3402.

4. An, G.H., S. Miyakawa, A. Kawahara, M. Osaki, and T. Ezawa. 2008. Community structure of arbuscular mycorrhizal fungi associated with pioneer grass species Miscanthus sinensis in acid sulfate soils: habitat segregation along pH gradients. Soil Sci. Plant Nutr. 54:517-528.

5. Augé, R.M. 2001. Water relations, drought and vesicular-arbuscular mycorrhizal symbiosis. Mycorrhiza 11:3-42.

6. Azcón-Aguilar, C., and J.M. Barea. 1996. Arbuscular mycorrhizas and biological control of soil-borne plant pathogens - an overview of the mechanisms involved. Mycorrhiza 6:457-464.

7. Beck, A., I. Haug, F. Oberwinkler, and I. Kottke. 2007. Structural characterization and molecular identification of arbuscular mycorrhiza morphotypes of Alzatea verticillata (Alzateaceae), a prominent tree in the tropical mountain rain forest of South Ecuador. Mycorrhiza 17:607-625.

8. Brabson, J.S., R.L. Dunn, E.Z. Epps, W.M. Jr. Hoffman, and K.D. Jacob. 1958. Report on phosphorus in fertilizers: photometric determination of total phosphorus, J. Assoc. Off. Anal. Chem. 41:517.

9. Brundrett, M., N. Bougher, B. Dell, T. Grove and N. Malajczuk. 1996. Working with Mycorrhizas in Forestry and Agriculture. Pirie Printers, Canberra, Australia.

10. Calvet, C., J. Pinochet, A. Camprubí, and C. Fernández. 1995. Increased tolerance to the root-lesion nematode Pratylenchus vulnus in mycorrhizal micropropagated BA-29 quince rootstock. Mycorrhiza. 5:253-258.

11. Camprubí, A., J. Pinochet, C. Calvet, and V. Estaun. 1993. Effects of the root-lesion nematode Pratylenchus vulnus and the vesicular arbuscular mycorrhizal fungus Glomus mosseae on the growth of three plum rootstocks. Plant Soil. 153:223-229.

12. Daft, M.J., and T.H. Nicolson. 1972. Effect of Endogone mycorrhiza on plant growth. IV. Quantiative relationships between the growth of the host and the development of the endophyte in tomato and maize. New Phytol. 71:287-295.

13. Douds, D.D., R.R. Janke, and S.E. Peters. 1993. VAM fungus spore populations and colonization of roots of maize and soybean under conventional and low-input sustainable agriculture. Agric. Ecosyst. Environ. 43:325-335.

14. Douds, Jr. D.D., and P.D. Millner. 1999. Biodiversity of arbuscular mycorrhizal fungi in agroecosystems. Agric. Ecosyst. Environ. 74:77-93.

15. Felsenstein, J. 1985. Confidence limits on phylogenies: an approach using the bootstrap. Evolution 39:783-791.

16. Gadiner, D.T., and N.W. Christensen. 1991. Pear seedling responses to phosphorus, fumigation and mycprrhizal inoculation. J. Hortic. Sci. 66:775-780.

17. Heikham, E., K. Roupam, and G. Bhoopander. 2009. Arbuscular mycorrhizal fungi in alleviation of salt stress: a review. Ann. Bot. 104:1263-1280. 
18. Helgason, T., and A.H. Fitter. 2009. Natural selection and the evolutionary ecology of the arbuscular mycorrhizal fungi (Phylum Glomeromycota). J. Exp. Bot. 60:2465-2480.

19. Helgason, T., A.H. Fitter., and J.P.W. Young. 1999. Molecular diversity of arbuscular mycorrhizal fungi colonizing Hyacinthoides non-scripta (bluebell) in a seminatural woodland. Mol. Ecol. 8:659666.

20. Hijri, I., Z. Sýkorová, F. Oehl, K. Ineichen, P. Mäder, A. Wiemken, and D. Redecker. 2006. Community of arbuscular mycorrhizal fungi in arable soils are not necessarily low in diversity. Mol. Ecol. 15:2277-2289.

21. Husband, R., E.A. Herre, S.L. Turner, R. Gallery, and J.P.W. Young. 2002. Molecular diversity of arbuscular mycorrhizal fungi and patterns of host association over time and space in a tropical forest. Mol. Ecol. 11:2669-2678.

22. Ishii, T., I. Matsumoto, Y.H. Shrestha, and K. Kadoya. 1999. Ecological aspects of vesicular-arbuscular mycorrhizal fungi in satsuma mandarin growth in plastic green houses and fields. J. Japan. Soc. Hort. Sci. 68:219-227.

23. Jasper, D.A., A.D. Robson, and L.K. Abbott. 1979. Phosphorus and the formation of vesicular-arbuscular mycorrhizas. Soil Biol. Biochem. 11:501-505.

24. Johnson, D., P.J. Vandenkoornhuyse, J.R. Leake, L. Gilbert, R.E. Booth, J.P. Grime, J.P.W. Young, and D.J. Read. 2003. Plant communities affect arbuscular mycorrhizal fungal diversity and community composition in grassland microcosms. New Phytol. 161:503-515.

25. Johnson, N.C. 1993. Can fertilization of soil select less mutualistic mycorrhizae? Ecol. Appl. 3:749-757.

26. Krüger, M., C. Krüger, C. Walker, H. Stockinger, and A. Schüßler. 2012. Phylogenetic reference data for systematic and phylotaxonomy of arbuscular mycorrhizal fungi from phylum to species level. New Phytol. 193:970-984.

27. Larkin, M.A., G. Blackshields, N.P. Brown, et al. 2007. Clustal W and Clustal X version 2.0. Bioinformatics 23:2947-2948.

28. Lee, J., S. Lee, and J.P.W. Young. 2008. Improved PCR primers for the detection and identification of arbuscular mycorrhizal fungi. FEMS Microbiol. Ecol. 65:339-349.

29. Liu, Y., G. Shi, L. Mao, et al. 2012. Direct and indirect influences of $8 \mathrm{yr}$ of nitrogen and phosphorus fertilization on Glomeromycota in an alpine meadow ecosystem. New Phytol. 194:523-535.

30. Lopez, A., J. Pinochet, C. Fernandez, C. Calvet, and A. Camprubi. 1997. Growth response of OHF-333 pear rootstock to arbuscular mycorrhizal fungi, phosphorus nutrition and Pratylenchus vulnus infection. Fund. Appl. Nematol. 20:87-93.

31. Marcel, G.A., M.G.A. van der Heijden, T. Boller, and A. Wiemken. 1998. Different arbuscular mycorrhizal fungal species are potential determinants of plant community structure. Ecology 79:2082-2091.

32. Meharg, A.A., and J.W.G. Cairney. 2000. Co-evolution of mycorrhizal symbionts and their hosts to metal-contaminated environments. Adv. Ecol. Res. 30:69-112.

33. Menge, J.A., D. Steirle, D.J. Bagyaraj, E.L.V. Johnson, and R.T. Leonard. 1978. Phosphorus concentrations in plants responsible for inhibition of mycorrhizal infection. New Phytol. 80:575-578.

34. Mosse, B. 1973. Plant growth responses to vesicular-arbuscular mycorrhiza. IV. In soil given additional phosphate. New Phytol. 72:127-136.

35. Obara, H., and M. Nakai. 2004. Available phosphate of arable lands in Japan. Changes of soil characteristics in Japanese arable lands (II) (In Japanese). Jpn. J. Soil Sci. Plant Nutr. 75:59-67.

36. Oehl, F., E. Sieverding, P. Mäder, D. Dubois, K. Ineichen, T. Boller, and A. Wiemken. 2004. Impact of long-term conventional and organic farming on the diversity of arbuscular mycorrhizal fungi. Oecologia 138:574-583.

37. Öpik, M., M. Moora, J. Liira, and M. Zobel. 2006. Composition of root-colonizing arbuscular mycorrhizal fungal communities in different ecosystems around the globe. J. Ecol. 94:778-790.
38. Page, R.D.M. 1996. An application to display phylogenetic trees on personal computers. Comp. Appl. Biosci. 12:357-358.

39. Pinochet, J., A. Camprubí, and C. Calvet. 1993. Effects of the root-lesion nematode Pratylenchus vulnus and the mycorrhizal fungus Glomus mosseae on the growth of EMLA-26 apple rootstocks. Mycorrhiza. 4:79-83.

40. Pinochet, J., C. Calvet, A. Camprubí, and C. Fernández. 1995. Interaction between the root-lesion nematode Pratylenchus vulnus and the mycorrhizal association of Glomus intraradices and Santa Lucia 64 cherry rootstock. Plant Soil. 170:323-329.

41. Rutto, K.L., F. Mizutani, D.G. Moon, and K. Kadoya. 2002. The relationship between cultural practices and arbuscular mycorrhizal (AM) activity in orchards under different management systems. J. Japan. Soc. Hort. Sci. 75:601-609.

42. Ryan, M.H., D.R. Small, and J.E. Ash. 2000. Phosphorus controls the level of colonization by arbuscular mycorrhizal fungi in conventional and biodynamic. Austr. J. Exp. Agric. 40:663-670.

43. Saitou, N., and M. Nei. 1987. The neighbor-joining method: a new method for reconstructing phylogenetic trees. Mol. Biol. Evol. 4:406425.

44. Schüßler, A., and C. Walker. 2010. The Glomeromycota: a species list with new families and new genera. http://www.amf-phylogeny.com. Accessed 8 Aug 2012.

45. Scullion, J., W.R. Eason, and E.P. Scott. 1998. The effectivity of arbuscular mycorrhizal fungi from high input conventional and organic grassland and grass-arable rotations. Plant Soil 204:243-254.

46. Smith, S.E., and D.J. Read. 2008. Mycorrhizal Symbiosis, 3rd ed. Academic Press, San Diego.

47. Smith, S.E., F.A. Smith, and I. Jakobsen. 2004. Functional diversity in arbuscular mycorrhizal (AM) symbioses: the contribution of the mycorrhizal $\mathrm{P}$ uptake pathway is not correlated with mycorrhizal responses in growth or total P uptake. New Phytol. 162:511-524.

48. Tawaraya, K., T. Kinebuchi, S. Watanabe, T. Wagatsuma, and M. Suzuki. 1996. Effect of arbuscular mycorrhizal fungi Glomus mosseae, Glomus fasiculatum and Glomus caledonium on phosphorus uptake and growth of Welsh Onion (Allium fistulosum L.) in andosols. Jpn. J. Soil Sci. Plant Nutr. 67:294-298.

49. ter Braak, C.F.J., and P. Smilauer. 2002. CANOCO Reference Manual and CanoDraw for Windows User's Guide: Software for Canonical Community Ordination (version 4.5). Biometris, Wageningen, The Netherland.

50. Thomson, B.D., A.D. Robson, and L.K. Abbott. 1986. Effects of phosphorus on the formation of mycorrhizas by Gigaspora calospora and Glomus fasciculatum in relation to root carbohydrates. New Phytol. 103:751-765.

51. Truog, E. 1930. The determination of readily available P in soils. J. Am. Soc. Agric. 22:874-890.

52. Vandenkoornhuyse, P., R. Husband, T.J. Daniell, I.J. Watoson, J.M. Duck, A.H. Fitter, and J.P.W. Young. 2002. Arbuscular mycorrhizal community composition associated with plant species in a grassland ecosystem. Mol. Ecol. 11:1555-1564.

53. Vandenkoornhuyse, P., K.P. Ridgway, I.J. Watson, A.H. Fitter, and J.P.W. Young. 2003. Co-existing grass species have distinctive arbuscular mycorrhizal communities. Mol. Ecol. 12:3085-3095.

54. Wubet, T., M. Weiß, I. Kottke, D. Teketay, and F. Oberwinkler. 2003. Molecular diversity of arbuscular mycorrhizal fungi in Prunus africana, an endangered medicinal tree species in dry Afromontane forests of Ethiopia. New Phytol. 161:517-528.

55. Yamato, M., S. Ikeda, and K. Iwase. 2009. Community of arbuscular mycorrhizal fungi in drought-resistant plants, Moringa spp., in semiarid regions on Madagascar and Uganda. Mycoscience 50:100105.

56. Youpensuk, S., S. Lordkaew, and B. Rerkasem. 2008. Arbuscular mycorrhizal fungi associated with tangerine (Citrus reticulata) in Chiang Mai province, northern Thailand, and their effects on the host plant. Science Asia 34:259-264. 